\title{
Let-7e sensitizes epithelial ovarian cancer to cisplatin through repressing DNA double strand break repair
}

\author{
Man Xiao ${ }^{1 \dagger}$, Jing Cai ${ }^{1 \dagger}$, Liqiong Cai ${ }^{1}$, Jinghui Jia ${ }^{2}$, Lisha Xie ${ }^{1}$, Ying Zhu', Bangxing Huang ${ }^{3}$, Dongdong Jin ${ }^{1}$
} and Zehua Wang ${ }^{1 *}$

\begin{abstract}
Background: Resistance to platinum-based chemotherapy remains a great challenge for ovarian cancer treatment. The human let-7 family contains 13 members located on nine different chromosomes, and most members have been implicated in the modulation of drug sensitivity in cancers. Our previous study showed that deregulation of let-7e in epithelial ovarian cancer (EOC) promoted the development of resistance to cisplatin. In the present study, we aimed to investigate the underlying mechanism and further evaluate the clinical value of let-7e in predicting chemo-response and prognosis in EOC.

Results: In situ hybridization assays revealed a significantly decreased expression of let-7e in chemo-resistant EOC tissues compared with chemo-sensitive cases. Transfection with let-7e agomir sensitized EOC cells to cisplatin, down-regulated BRCA1 and Rad51 expression, and repressed the repair of cisplatin-induced DNA double strand break, while let-7e inhibitor exerted the opposite effects. In human EOC tissues, BRCA1 and Rad51 levels were increased in the chemo-resistant group compared with the sensitive group and were negatively correlated with let-7e. Low let-7e and high Rad51 were significantly associated with poor progression-free survival and overall survival and multivariate regression analyses showed that let-7e was an independent predictor for overall survival and chemotherapy response in EOC. Receiver operating characteristic analysis indicated that let-7e level was highly predictive of resistance to platinum-taxane chemotherapy with an area under the curve of 0.826 .
\end{abstract}

Conclusions: In EOC, low let-7e leads to activation of BRCA1 and Rad51 expression and subsequent enhancement of DSB repair, which in turn results in cisplatin-resistance. Let-7e is a potential predictor for survival and chemoresponse in EOC and re-expression of let-7e might be an effective strategy for overcoming chemo-resistance.

Keywords: Let-7e, Ovarian cancer, Cisplatin, DSB, BRCA1, Rad51

\section{Background}

Ovarian cancer remains one of the leading causes of gynecological-cancer-associated death [1]. Late diagnosis and chemotherapy resistance account for the stubbornly high mortality associated with ovarian cancer. Platinum drugs are the most widely used first-line chemotherapy agents for treatment of epithelial ovarian cancer (EOC), which exert cytotoxic effect through reacting with DNA

\footnotetext{
*Correspondence: zehuawang@163.net

${ }^{\dagger}$ Equal contributors

'Department of Obstetrics and Gynecology, Union Hospital, Tongji Medical College, Huazhong University of Science and Technology, No. 1277 Jiefang Avenue, Wuhan 430022, China

Full list of author information is available at the end of the article
}

and subsequently inducing intra- or inter-strand crosslink or single nucleotide damage. Inter-strand cross-link can lead to double strand break (DSB) that represents a form of lethal DNA damage and can be repaired through homologous recombination (HR) and non-homologous end-joining (NHEJ) [2]. HR is thought to be a conserved and error-free pathway to repair DSB compared with NHEJ, which is regarded as imprecise and potentially mutagenic [2, 3]. In addition, HR is related with cisplatin sensitivity in several solid tumors such as esophageal squamous carcinoma and embryonal carcinoma $[4,5]$. The inhibition of HR repair capacity could effectively sensitize ovarian cancer cells to cisplatin [6]. However, 
the regulatory mechanism for HR repair of cisplatininduced DSB is largely unknown.

MicroRNAs (miRNAs) represent a class of non-coding RNAs ( 22 nt) with regulatory functions through complete or incomplete base paring with the 3' untranslated region (UTR) of target genes, leading to RNA degradation or translation repression [7]. To date, enormous evidence has highlighted the implication of miRNAs in chemo-resistant phenotype of cancers. Down-regulation of miR-186, miR-203, miR-181b or miR-497 could influence the sensitivity of ovarian, breast, lung or gastric cancer to cisplatin treatment $[8$, 9]. As the second discovered miRNA after lin-4, let-7 was first identified in 2000, and its 13 family members share sequence homology in seed regions. Emerging data suggest that let-7 family members display different activities, and most members have been implicated in the modulation of drug sensitivity in cancers [10]. Our previous study indicated that over-expression of let-7e increased the sensitivity to cisplatin in EOC cells in vitro and in vivo [11]. Nevertheless, the underlying mechanism remains unclear. The DNA damage induced by ionizing radiation significantly altered the expression of let$7 \mathrm{e}[12,13]$, and let-7e was identified as one of the miRNAs that influenced $\gamma \mathrm{H} 2 \mathrm{AX}$ foci formation [14], which is a surrogate marker of DSB [15]. We therefore hypothesized that let-7e regulates the response to cisplatin in EOC through impacting the repair of cisplatin-induced DSB. In this study, we provided evidence supporting the involvement of let-7e in DSB repair and cisplatinresistance and explored the prognostic values of let-7e and two key factors implicated in HR repair, BRCA1 and Rad51, for survival and chemo-response in EOC.

\section{Methods}

\section{Patients and tissue samples}

A total of 84 tissue samples obtained from EOC patients (median age, 52 years; range, 32-72 years) who underwent primary surgery and adjuvant platinum-based chemotherapy at Wuhan Union Hospital between August 2008 and October 2015 were studied. All patients received radical surgery followed by standard platinum-taxane chemotherapy. Chemo-resistant tumors were defined as those with relapse within six months after completing chemotherapy or progress during the primary chemotherapy [16]. The relapses were diagnosed based on clinical symptoms, radiological evidence or rising CA125 [16]. The medical records of patients were reviewed to collect data regarding clinicopathological characteristics and treatment. The following parameters were recorded: age, histological subtypes, International Federation of Gynecology and Obstetrics (FIGO) stage, tumor categories and chemotherapy response. In addition, the follow-up data (median, 25 months; range, 459 months) were collected. Overall survival (OS) was defined as the time from initial resection to death or the last follow-up date; profession-free survival (PFS) was defined as the time from surgery to relapse or the last followup date. The diagnosis was pathologically confirmed in all patients and the patients who underwent chemotherapy or radiotherapy prior to surgery were excluded.

Formalin-fixed and paraffin embedded (FFPE) tissues were used for in situ hybridization (ISH) and immunohistochemistry (IHC). H\&E staining was performed for each paraffin block to exclude those noncancerous blocks. The use of specimens and archiving of patient data were approved by the ethical committee of Union Hospital.

\section{ISH}

The detection of let-7e expression in FFPE ovarian cancer tissues was performed according to the robust oneday ISH protocol based on the use of double digoxigenin (DIG)-labeled Locked Nucleic Acids (LNA) probes (Exiqon, Denmark), which retain a larger difference in melting temperature between a complementary target and a highly similar target sequences and have the ability to discriminate highly similar miRNA family members at the optimized hybridization temperature, like the let-7 family members [17]. Only those tissues with positive U6 expression were admitted for subsequent let-7e detection to exclude false-negative results. In short, after deparaffinization in xylene and graded ethanol dilution, six-micrometer sections were treated with $15 \mu \mathrm{g} / \mathrm{ml}$ proteinase- $\mathrm{K}$ at $37{ }^{\circ} \mathrm{C}$ for $7 \mathrm{~min}$ and dehydrated with ethanol. The sections were hybridized with $1 \mathrm{nM}$ U6 snRNA and $20 \mathrm{nM}$ let-7e or a scramble control probe at $60{ }^{\circ} \mathrm{C}$ for $1 \mathrm{~h}$. Coverslips were sealed with Fixogum Rubber Cement during hybridization. A strict wash was then performed in pre-heated standard saline citrate (SSC) buffers at $60{ }^{\circ} \mathrm{C}$ for $5 \mathrm{~min}$ each: once in $5 \times \mathrm{SSC}$, twice in $1 \times$ SSC, twice in $0.2 \times$ SSC and once in $0.2 \times$ SSC at room temperature. The samples were rinsed with $\mathrm{PBS}$ containing 0.1\% Tween-20 (PBST) solutions and blocked in blocking solution ( $2 \%$ sheep serum, $1 \%$ bovine serum albumin in PBST) for $15 \mathrm{~min}$ at room temperature. Thereafter, the samples were incubated with an alkaline phosphatase (AP)-conjugated anti-DIG antibody (1:1600 dilution; Roche, Mannheim, Germany) at room temperature for $60 \mathrm{~min}$. After washing twice in PBST, the sections were incubated with NBT/BCIP (Roche) complemented with $0.2 \mathrm{mM}$ Levamisole Hydrochloride (TGI, Tokyo, Japan) at $30{ }^{\circ} \mathrm{C}$ for $2 \mathrm{~h}$ to develop the dark-blue NBT-formazan precipitate. Slides were then washed twice in KTBT buffer and counterstained with nuclear fast red (Vector Laboratories, CA, USA).

\section{IHC}

Sections $(4 \mu \mathrm{m}$ thick) were dewaxed in xylene and rehydrated through descending ethanol series to water. 
Antigen retrieval was performed in citrate buffer $(\mathrm{PH}$ 6.0) through microwave irradiation. After endogenous peroxidase being blocked with $3 \%$ hydrogen peroxide, slides were incubated with polyclonal rabbit anti-BRCA1 (1:100 dilution; Proteintech Group, Chicago, USA) or anti-Rad51 polyclonal antibody (1:100 dilution; Santa Cruz, Texas, USA) at $4{ }^{\circ} \mathrm{C}$ overnight and then treated with a biotinylated secondary antibody at room temperature for $30 \mathrm{~min}$. After that, further incubation with horseradish peroxidase labeled avidin, DAB color development and counterstaining with hematoxylin were performed. Negative controls were accomplished by replacing the primary antibody with PBS.

\section{Scoring of ISH and IHC}

The expression of let-7e, BRCA1 and Rad51 were evaluated independently by two pathologists blinded to the patient data of the samples. In case of discrepancy, the slide was reexamined by the third pathologist. In each slide, the proportion and intensity of positive staining of tumor cells were evaluated in five randomly selected high-power fields and a staining score (0-9) was determined by multiplying the positive proportion score $(0$, $0 \% ; 1,<25 \% ; 2,25-50 \% ; 3,>50 \%)$ with the staining intensity score ( 0 , negative; 1 , light blue or yellow; 2 , blue or yellow; 3, dark blue or yellow). The median scores were used as the cutoff values to define the high and low expression of let-7e, BRCA1 and Rad51.

\section{Cell lines and cell culture}

The A2780, HO8910, ES2, CAOV3 and $\mathrm{SKOV}_{3}$ human epithelial ovarian cancer cell lines were obtained from China Center for Type Culture Collection (CCTCC). The cisplatin-sensitive cell line OV2008 and its resistant variant $\mathrm{C} 13 \mathrm{~K}$ were initially obtained from Dr. Rakesh Goel of the Ottawa Regional Cancer Center, Canada and stored in our laboratory. Cells were cultured in Dulbecco's Modified Eagle Medium (DMEM) supplemented with $10 \%$ fetal bovine serum under a humidified atmosphere containing $5 \% \mathrm{CO}_{2}$ at $37^{\circ} \mathrm{C}$.

\section{Transfections}

The let-7e agomir and inhibitor were synthesized by Genepharma (Shanghai, China). As the cholesterol-conjugated 2'-O-methyl-modified miRNA mimics, miRNA agomir has a greater affinity for cell membrane and can function stronger and longer. MiRNA inhibitors are 2'-O-methylmodified oligoribonucleotides with the ability to effectively and sequence-specifically block RISC-associated miRNP (miRNA-containing ribonucleic protein) activity. Twentyfour hours before transfection, cells were seeded in a sixwell plate at a concentration of $4 \times 10^{5}$ cells per well. Upon reaching $60-70 \%$ confluence, cells were transfected with $30 \mathrm{nM}$ let-7e agomirs, $200 \mathrm{nM}$ let-7e inhibitors, or corresponding negative control using PEI according to the manufactures instructions. The transfection efficiency was verified by qRT-PCR.

\section{MTT assay}

After transfection, a density of 5000 cells per well were seeded onto 96-well plates and exposed to a series of cisplatin for $48 \mathrm{~h}$. MTT reagent (at a final concentration of $10 \%$; Sigma, USA) was then added to each well and further incubated for $4 \mathrm{~h}$ at $37^{\circ} \mathrm{C}$ before $100 \mu$ lysis buffer (10 g of SDS, $5 \mathrm{ml}$ isopropanol and $1 \mathrm{ml} 1 \mathrm{mM}$ hydrochloric acid) was added to dissolve the MTT formazan product. Absorbance at $570 \mathrm{~nm}$ was measured with a microplate reader (Bio-Rad, Hercules, CA, USA) and cellular survival fractions were calculated by normalizing the optical density of cisplatin treated wells to that of untreated controls.

\section{Colony-formation assay}

Approximately five hundred transfected cells per well were plated into six-well plates and incubated with cisplatin for $48 \mathrm{~h}$ and then allowed to recover for two weeks. Colonies derived from surviving cells were stained with $0.1 \%$ crystal violet and those more than 50 cells per colony were counted manually.

\section{Real-time PCR for let-7e}

Total RNA of cultured cells were extracted using Trizol (Takara, Japan) and their quality and quantity were checked by Nanodrop 2000 (Thermo Scientific, Waltham, MA, USA) before the synthesis of cDNA using the RevertAid First Strand complementary DNA Synthesis Kit (Thermo Scientific). Bulge-Loop ${ }^{\text {tw }}$ hsa-let-7e-5p qRT-PCR Primer Set (RiboBio, Guangzhou, China) was used to analyze the expression of let-7e according to the manufacturer's instructions. The universally expressed U6 snRNA (RiboBio) was used for let-7e normalization. PCR reactions were carried out on an ABI PRISM 7300 Step-One Plus instrument (Applied Biosystems, Foster City, CA, USA) with SYBR Green PCR Master Mix (Takara). The cycling method for the reverse transcription reaction was as follows: $70{ }^{\circ} \mathrm{C}$ for $10 \mathrm{~min}, 2 \mathrm{~min}$ on ice followed by $42{ }^{\circ} \mathrm{C}$ for $1 \mathrm{~h}$ and $70{ }^{\circ} \mathrm{C}$ for $10 \mathrm{~min}$. The cycling conditions of PCR consist of an initial denaturizing step of 20 s at $95{ }^{\circ} \mathrm{C}$ and 40 cycles of denaturing at $95{ }^{\circ} \mathrm{C}$ for $10 \mathrm{~s}$, annealing at $60{ }^{\circ} \mathrm{C}$ for 20 s and extension at $70{ }^{\circ} \mathrm{C}$ for 10 s.

\section{Real-time PCR for mRNA expression}

After total RNA was isolated from cells, the cDNA was synthesized based on the universal primers using a reverse transcription kit (Takara). The sequences of PCR primers were displayed in Additional file 1: Table S1. $\beta$ actin was used as internal control. The PCR profile was 
$95{ }^{\circ} \mathrm{C}$ for $1 \mathrm{~min}$, and then followed by 40 cycles of $95{ }^{\circ} \mathrm{C}$ for $15 \mathrm{~s}, 60{ }^{\circ} \mathrm{C}$ for $1 \mathrm{~min}$. Each reaction was performed in triplicate.

\section{Single-cell gel electrophoresis (Comet assay)}

To evaluate the repair capacity of DSB caused by cisplatin, approximately 50000 ovarian cancer cells per well were seeded into 12-well plates and treated with low concentration of cisplatin $(3 \mu \mathrm{M}$ for A2780, $5 \mu \mathrm{M}$ for OV2008) for $8 \mathrm{~h}$. After incubation, cultures were allowed to recover for $0,4,8$ and $24 \mathrm{~h}$. Thereafter, cells were trypsinized and harvested. Approximately $2 \times 10^{4}$ cells per aliquot were suspended with $20 \mu \mathrm{l}$ PBS.

To detect DSB, neutral comet assays ( $\mathrm{pH}$ 8.5) were performed as described by Wojewodzka $\mathrm{M}$ et al. [18] with slight modification. In brief, fully frosted microscope slides were covered with $1 \%$ normal melting point agarose (the first layer) and $0.5 \%$ low melting point agarose (LMP, the second layer) sequentially. Then, $100 \mu \mathrm{l}$ of the mixture of $0.7 \%$ LMP agarose and cell suspension (the third layer) was pipetted onto the center of the second agarose layer. At each step, sides were placed on ice for 10-15 min to allow the agarose to solidify and maintain cooling. After that, slides were immersed into icecold lysis solution $(2.5 \mathrm{M} \mathrm{NaCl}, 100 \mathrm{mM} \mathrm{Na} 2$ EDTA,

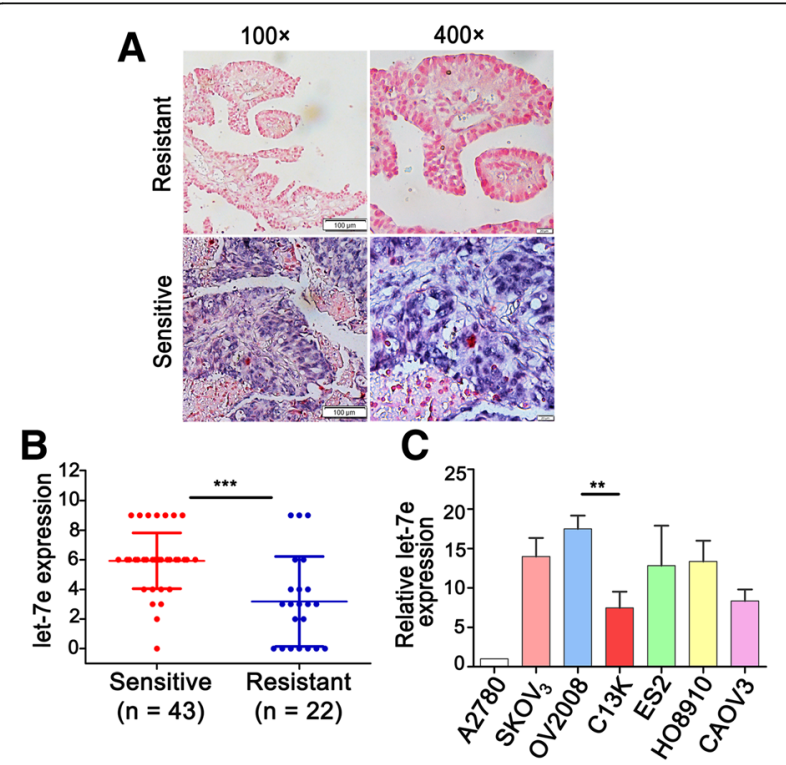

Fig. 1 Let-7e expression is significantly decreased in chemo-resistant epithelial ovarian cancer (EOC). a Representative images of let-7e via in situ hybridization in one of the chemo-resistant (upper) versus chemo-sensitive (down) ovarian cancer specimens. The positive let-7e LNA-ISH signal is blue. $\mathbf{b}$ The corresponding histogram of the semi-quantification of let-7e level in two groups. Mann Whitney test, ${ }^{* * *} P<0.0001$. c Validation of let-7e using qRT-PCR in seven ovarian cancer cell lines. C13K is the corresponding cisplatin-resistant variants of ovarian cancer cell OV2008. The let-7e level in A2780 were set as 1. Student's t-test, ${ }^{* *} P<0.01$
$10 \mathrm{mM}$ Tris- $\mathrm{HCl}$ and $1 \%$ Triton $\mathrm{X}-100$ ) at $4{ }^{\circ} \mathrm{C}$ for $1.5 \mathrm{~h}$. The slides were then directly placed in neutral electrophoresis buffer $(300 \mathrm{mM}$ sodium acetate, $100 \mathrm{mM}$ Tris- $\mathrm{HCl}, \mathrm{pH}$ 8.5) and left for $30 \mathrm{~min}$ before being electrophoresed at $16 \mathrm{~V}$ and $50 \mathrm{~mA}(0.4 \mathrm{~V} / \mathrm{cm})$ for $1 \mathrm{~h}$ on ice. After that, slides were stained with $10 \mu \mathrm{l}$ of $2 \mu \mathrm{g} / \mathrm{ml}$ ethidium bromide and visualized with a microscope at a $4 \times$ objective.

Comet Assay Software Project (CASP) was used for image analysis. Tail moment (TM, the length of the comet tail multiplied by the intensity of fluorescence in the tail) [19] was used to quantify the DNA damage. The residual DNA damage of cells over a recovery period of 4,8 and 24 h was normalized to that of freshly harvested cells after incubation with cisplatin. One hundred randomly selected cells for each group were analyzed in three separate experiments.

\section{Detection of $\mathrm{Y}-\mathrm{H} 2 \mathrm{AX}$ foci by immunofluorescence}

In response to DSB, the histone $\mathrm{H} 2 \mathrm{AX}$ is phosphorylated by ataxia telangiectasia mutated (ATM) and ataxia Rad3related (ATR) kinases and recruited to the site of damage along with an extensive network of proteins. In general, $\gamma$-H2AX foci (clusters of phosphorylated H2AX) has been widely applied as a surrogate marker of DSB after cellular exposure to ionizing radiation (IR) or drugs [15]. After transfection, cells were grown on coverslips in a 24-well plate $(20,000$ cells/well) and treated with cisplatin $\left(3 \mu \mathrm{M}\right.$ for A2780, $5 \mu \mathrm{M}$ for $\left.\mathrm{SKOV}_{3}\right)$ for $8 \mathrm{~h}$. Then cells were allowed to recover for another $8 \mathrm{~h}$ before fixed with $4 \%$ paraformaldehyde. After washing with PBS, cells were permeabilized with $0.5 \%$ Triton X-100 for $30 \mathrm{~min}$, blocked with $3 \%$ bovine serum albumin (BSA) containing $0.1 \%$ Tween-20 for $1 \mathrm{~h}$ and immunostained with antibody against $\gamma-\mathrm{H} 2 \mathrm{AX}$ (1:400 dilution; Cell Signaling Technology, Danvers, MA, USA) overnight at $4{ }^{\circ} \mathrm{C}$, followed by incubation with Cy3-labled antibody to Rabbit IgG (H + L) (1:1000 dilution; KPL, Gaithersburg, MD, USA) at room temperature for $1 \mathrm{~h}$. Then nuclei were counterstained with DAPI $(100 \mathrm{ng} / \mathrm{ml}$; Roche). Coverslips with cells were sealed before acquiring images with an A1-Si Nikon confocal laser scanning microscope. At least 100 cells per experiment were evaluated and cells with five or more foci were defined as positive. Results were expressed as the percentage of cells with positive $\gamma$-H2AX foci from three independently replicated experiments.

\section{Western blotting}

Proteins from whole cell lysates were separated by $10 \%$ SDS-PAGE gel and transferred to a polyvinylidene fluoride membrane (Bio-Rad, Hercules, CA, USA). The membrane was then blocked and incubated with rabbit antiBRCA1 (1:600 dilution; Proteintech Group, Chicago, 

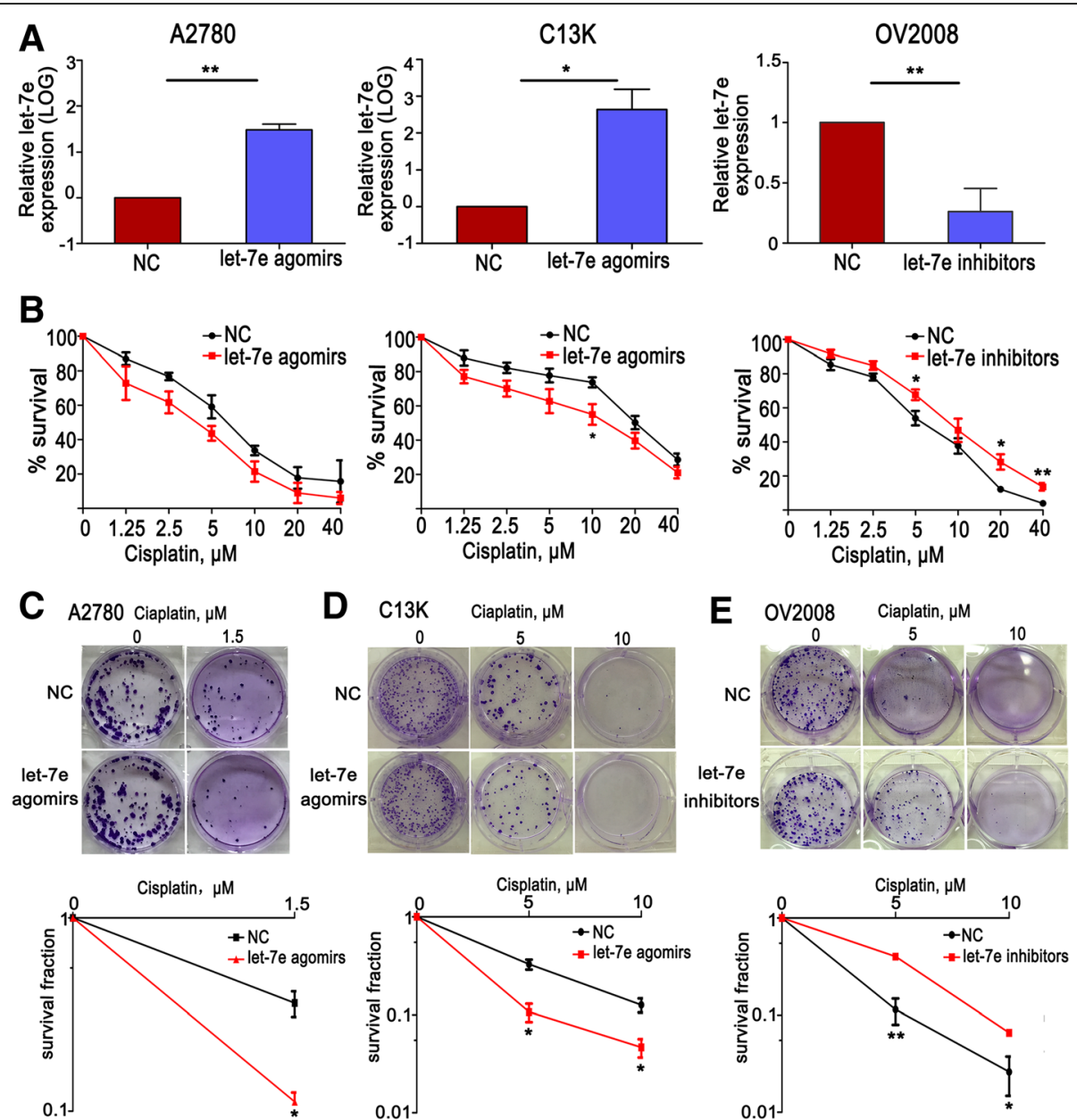

Fig. 2 Overexpression of let-7e increases the sensitivity of ovarian cancer cell lines to cisplatin. a qRT-PCR analyses of let-7e expression in A2780, C13K and OV2008 after transfection with let-7e agomirs or inhibitors. b Cell viability was assessed by MTT assay after incubation with a series of cisplatin. $\mathbf{c}$, $\mathbf{d}$ and $\mathbf{e}$ Clonogenic cell-survival assay analysis of cell viability after transfected with let-7e agomirs or inhibitors and treated with cisplatin. Representative images of colonies formed by A28780, C13K and OV2008 cell lines and the corresponding statistic graphs are shown. Student's $t$-test, ${ }^{*} P<0.05,{ }^{* *} P<0.01$

USA), rabbit anti-Rad51 (1:750 dilution; Santa Cruz, Texas, USA) or mouse anti $\beta$-actin (1:4000 dilution; Proteintech Group) at $4{ }^{\circ} \mathrm{C}$ overnight. Peroxidase-labeled anti-rabbit or anti-mouse secondary antibodies (1:5000 dilution; KPL, Gaithersburg, MD, USA) were used to detect the specific protein-antibody complex. Bands were visualized by an ECL substrate (Bio-Rad) and scanned using Image Lab Software in Molecular Imager ${ }^{\circ} \mathrm{Chemi}^{-}$ Doc $^{\mathrm{TM}}$ XRS+ (Bio-Rad). Equal protein loading was verified by $\beta$-actin signal.

\section{Statistical analysis}

All statistical analyses were carried out with the SPSS 20.0 software (SPSS). Students $t$-test or Mann Whitney test were used for comparisons between groups as appropriate. The relationship between the expression of let-7e, BRCA1 and Rad51 and EOC clinicopathological characteristics was analyzed by Fisher exact test. Survival curves were estimated by Kaplan-Meier method and compared with log-rank test. The risk for patient survival and chemotherapy response were assessed by Cox and logistic regression analyses, respectively. Receiver operating characteristic (ROC) curve analyses were performed to evaluate the capacity of let-7e, BRCA1 and Rad51 to predict chemotherapy response of EOC. P values less than 0.05 were considered statistically significant.

\section{Results}

Let-7e is correlated with chemo-resistance in epithelia ovarian cancer

To determine whether let-7e plays a role in the generation of chemotherapy resistance in EOC, we compared let-7e expression in chemo-resistant EOC $(n=22)$ versus chemo-sensitive EOC $(n=43)$ using ISH. The results 

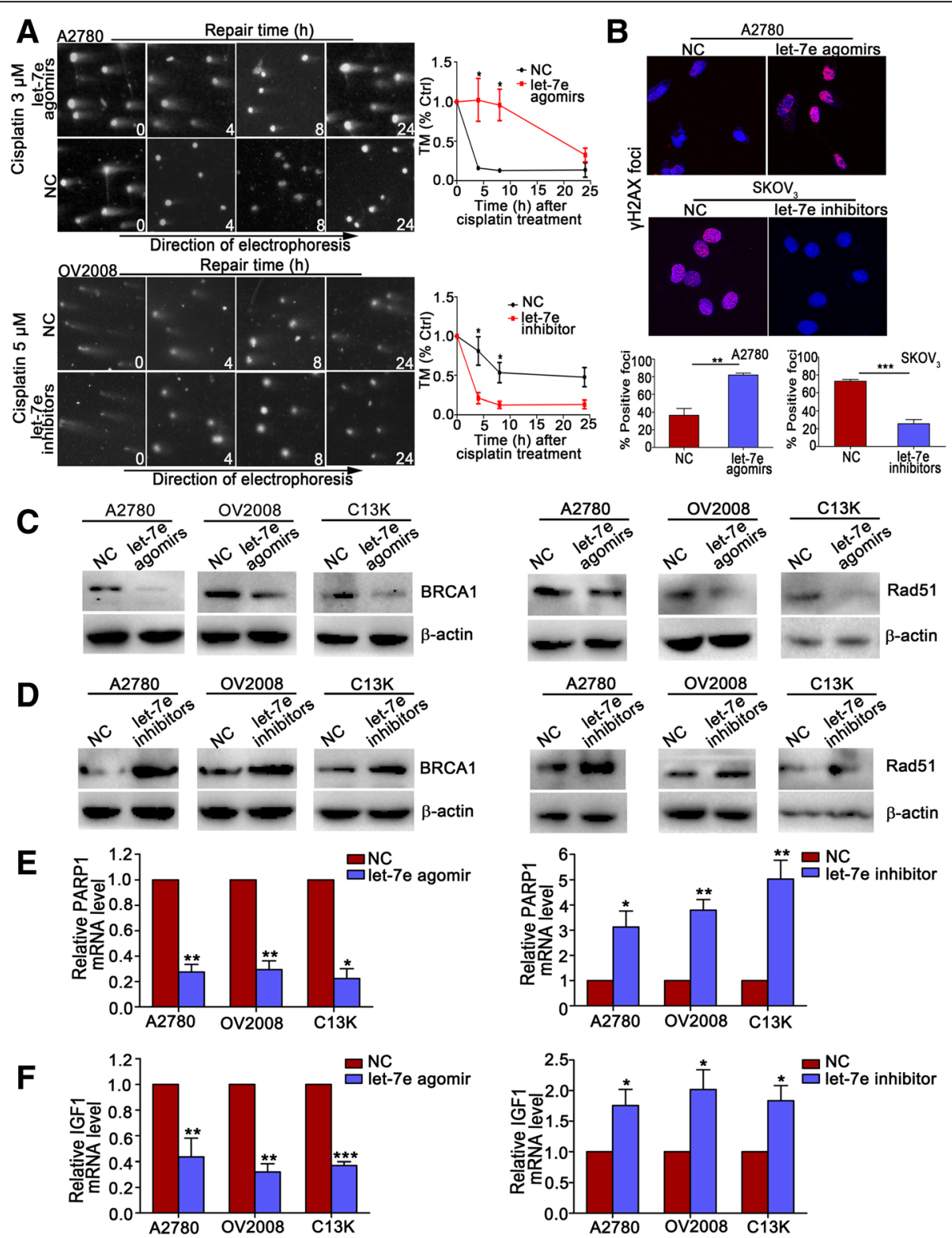

Fig. 3 Overexpression of let-7e decreases the DSB repair capacity of EOC cell lines treated with cisplatin. a DSB repair dynamics of transfected A2780 and OV2008 cells after treatment with cisplatin measured by neutral comet assay. The TM values measured at $0 \mathrm{~h}$ was set as $100 \%$ and residual DNA damage at 4, 8, $24 \mathrm{~h}$ after cisplatin incubation was expressed as percent of that at $0 \mathrm{~h}$. Representative images are shown on the left and the mean $\pm S D$ for each group in the right panel. b After treatment with cisplatin, $\gamma-\mathrm{H} 2 \mathrm{AX}$ foci in A2780 transfected with let-7e agomirs and $\mathrm{SKOV}_{3}$ with let-7e inhibitors were examined $8 \mathrm{~h}$ after recovery. The percentage of positive cells (with five or more foci) were used for the comparison between groups. Representative images and the mean \pm SD for each group are shown. $\mathbf{c}$ and $\mathbf{d}$ Western bolt shows the BRCA1 and Rad51 levels of cell lines transfected with let-7e agomirs or inhibitors. e and $\mathbf{f}$ qRT-PCR analyses show the mRNA levels of PARP1 and IGF1 in cell lines transected with let-7e agomirs or inhibitors. Student's $t$-test, ${ }^{*} P<0.05,{ }^{* *} P<0.01,{ }^{* * *} P<0.001$

showed a significantly decreased let-7e expression in the chemo-resistant EOC (Fig. 1a and b). Next, let-7e expression was assessed in seven ovarian cancer cell lines. Let-7e was detectable in all seven cell lines with the lowest level in A2780 and the highest level in OV2008. Moreover, the let-7e expression was significantly higher in OV2008 compared with its paired resistant line C13K (Fig. 1c). These results suggest that the decreased expression of let-7e may be involved in the development of resistance to platinum-based chemotherapy in EOC.

We next examined the effect of let-7e on cytotoxicity of cisplatin. The let-7e expression was manipulated by agomir and inhibitor (Fig. 2a). Since miRNA inhibitor technologies rely on competitively inhibited the effect of miRNA on their target genes, we detected the influence of let-7e inhibitor on the mRNA levels of RFX6 (regulatory factor X 6) [20], 


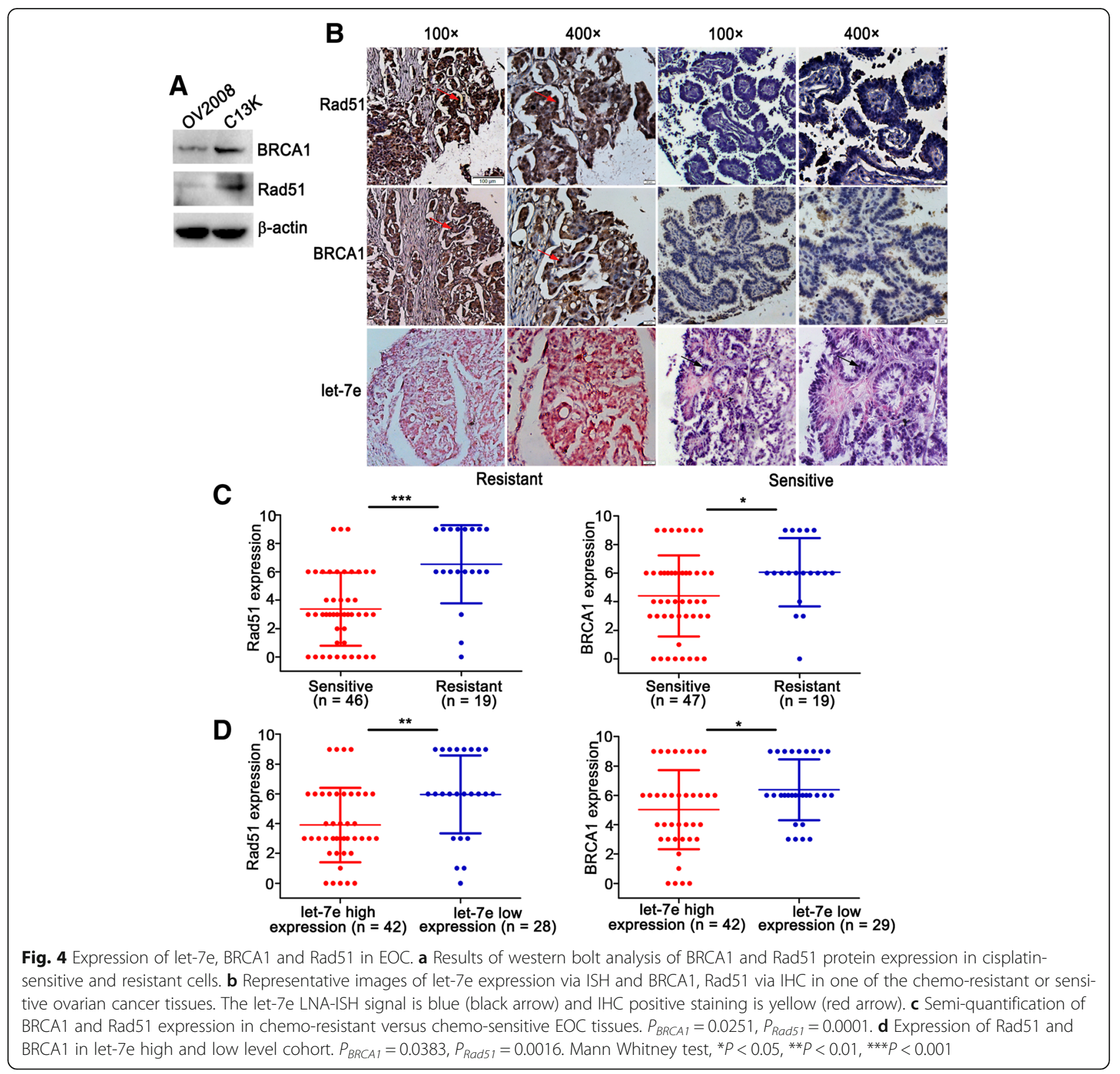

caspase 3 (CASP3) [21], matrix metalloproteinase-9 (MMP9) [22] and enhancer of zeste 2 (EZH2) [23], which have been validated to be the target genes of let-7e by luciferase reporter assays. We found that treatment with let7e inhibitor could up-regulate the mRNA levels of all these genes (Additional file 2: Figure S1). These results confirmed the effectiveness of let-7e inhibitor. Then, we performed MTT assays to detect the corresponding alterations in cisplatin cytotoxicity. As shown in Fig. 2b, transfection of let-7e agomir decreased the $\mathrm{IC}_{50}$ of cisplatin from $6.60 \mu \mathrm{M}$ to $3.66 \mu \mathrm{M}$ in A2780 cells $(P=0.084)$, and from $20.05 \mu \mathrm{M}$ to $9.66 \mu \mathrm{M}$ in C13K cells $(P=0.012)$. Inversely, treatment with let-7e inhibitor increased the $\mathrm{IC}_{50}$ of ciaplatin in OV2008 cells from $5.77 \mu \mathrm{M}$ to $9.46 \mu \mathrm{M}$
$(P=0.042)$. The effect of let-7e on response to cisplatin was further confirmed in colony-formation assays (Fig. 2c-e). These results confirm that the low let-7e expression in EOC is associated with platinum-resistance.

\section{Let-7e leads to defect in repair of DNA double-strand} break induced by cisplatin

Enhanced DNA DSB repair is an important mechanism of drug resistance. Having clarified the role of let-7e in cisplatin-resistance, we next wondered whether let-7e influences the repair capacity of DSB induced by cisplatin in EOC. We assessed the kinetics of DSB repair in EOC cells after exposure to cisplatin by using neutral single-cell electrophoresis. As shown in Fig. 3a, the DSB induced by 
Table 1 Associations of let-7e, BRCA1 and Rad51 expression with clinicopathological characteristics of EOC patients

\begin{tabular}{|c|c|c|c|c|c|c|c|c|c|c|c|}
\hline \multirow{2}{*}{$\begin{array}{l}\text { Clinicopathological } \\
\text { Features }\end{array}$} & \multirow{2}{*}{$\begin{array}{l}\text { No. of } \\
\text { Cases }\end{array}$} & \multicolumn{3}{|c|}{ Let-7e expression No.(\%) } & \multirow{2}{*}{$\begin{array}{l}\text { No. of } \\
\text { Cases }\end{array}$} & \multicolumn{3}{|c|}{ BRCA1 expression No.(\%) } & \multicolumn{3}{|c|}{ Rad51 expression No.(\%) } \\
\hline & & Low & High & $\begin{array}{l}P \text { Value } \\
a\end{array}$ & & Low & High & $\underset{a}{P \text { Value }}$ & Low & High & $\begin{array}{l}P \text { V Value } \\
\text { a }\end{array}$ \\
\hline \multicolumn{12}{|l|}{ Age at surgery, $y$} \\
\hline$<50$ & 25 & $\begin{array}{l}10 \\
(40.0)\end{array}$ & $\begin{array}{l}15 \\
(60.0)\end{array}$ & 1 & 26 & $\begin{array}{l}11 \\
(42.3)\end{array}$ & $\begin{array}{l}15 \\
(57.7)\end{array}$ & 0.800 & $\begin{array}{l}11 \\
(42.3)\end{array}$ & $\begin{array}{l}15 \\
(57.7)\end{array}$ & 0.126 \\
\hline$\geq 50$ & 40 & $\begin{array}{c}15 \\
(37.5)\end{array}$ & $\begin{array}{c}25 \\
(62.5)\end{array}$ & & 39 & $\begin{array}{c}19 \\
(48.7)\end{array}$ & $\begin{array}{c}20 \\
(51.3)\end{array}$ & & $\begin{array}{l}25 \\
(64.1)\end{array}$ & $\begin{array}{c}14 \\
(35.9)\end{array}$ & \\
\hline \multicolumn{12}{|l|}{ Histological subtypes } \\
\hline Serous & 53 & $\begin{array}{l}22 \\
(41.5)\end{array}$ & $\begin{array}{l}31 \\
(58.5)\end{array}$ & 0.344 & 52 & $\begin{array}{l}24 \\
(46.2)\end{array}$ & $\begin{array}{l}28 \\
(53.8)\end{array}$ & 1 & $\begin{array}{l}27 \\
(51.9)\end{array}$ & $\begin{array}{l}25 \\
(48.1)\end{array}$ & 0.355 \\
\hline Others & 12 & $3(25.0)$ & $9(75.0)$ & & 13 & $6(46.2)$ & $7(53.8)$ & & $9(69.2)$ & $4(30.8)$ & \\
\hline \multicolumn{12}{|l|}{ FIGO stage } \\
\hline$|-| \mid$ & 17 & $5(29.4)$ & $\begin{array}{c}12 \\
(70.6)\end{array}$ & 0.563 & 18 & $9(50.0)$ & $9(50.0)$ & 0.784 & $\begin{array}{c}13 \\
(72.2)\end{array}$ & $5(27.8)$ & 0.104 \\
\hline III-IV & 48 & $\begin{array}{c}20 \\
(41.7)\end{array}$ & $\begin{array}{c}28 \\
(58.3)\end{array}$ & & 47 & $\begin{array}{c}21 \\
(44.7)\end{array}$ & $\begin{array}{c}26 \\
(55.3)\end{array}$ & & $\begin{array}{c}23 \\
(48.9)\end{array}$ & $\begin{array}{c}24 \\
(51.1)\end{array}$ & \\
\hline \multicolumn{12}{|l|}{ Tumor categories } \\
\hline Type I & 15 & $3(20.0)$ & $\begin{array}{c}12 \\
(80.0)\end{array}$ & 0.133 & 16 & $8(50.0)$ & $8(50.0)$ & 0.778 & $\begin{array}{c}11 \\
(68.7)\end{array}$ & $5(31.3)$ & 0.258 \\
\hline Type II & 50 & $\begin{array}{c}22 \\
(44.0)\end{array}$ & $\begin{array}{c}28 \\
(56.0)\end{array}$ & & 49 & $\begin{array}{c}22 \\
(44.9)\end{array}$ & $\begin{array}{c}27 \\
(55.1)\end{array}$ & & $\begin{array}{c}25 \\
(51.0)\end{array}$ & $\begin{array}{c}24 \\
(49.0)\end{array}$ & \\
\hline \multicolumn{12}{|c|}{ Chemotherapy response } \\
\hline Sensitive & 43 & $8(18.6)$ & $\begin{array}{c}35 \\
(81.4)\end{array}$ & $<0.0001$ & 46 & $\begin{array}{c}26 \\
(56.5)\end{array}$ & $\begin{array}{c}20 \\
(43.5)\end{array}$ & 0.013 & $\begin{array}{c}33 \\
(71.7)\end{array}$ & $\begin{array}{c}13 \\
(28.3)\end{array}$ & $<0.0001$ \\
\hline Resistant & 22 & $\begin{array}{c}17 \\
(77.3)\end{array}$ & $5(22.7)$ & & 19 & $4(21.1)$ & $\begin{array}{c}15 \\
(78.9)\end{array}$ & & $3(15.8)$ & $\begin{array}{c}16 \\
(84.2)\end{array}$ & \\
\hline
\end{tabular}

EOC epithelial ovarian cancer, FIGO International Federation of Gynecology and Obstetrics

${ }^{\text {a }}$ Fisher exact test

cisplatin treatment began to recover $4 \mathrm{~h}$ after cisplatin stimulation in control A2780 cells, whereas increased let-7e expression led to a dramatically delayed DSB repair. Conversely, down-regulation of let-7e in OV2008 cells resulted in an accelerated DSB repair compared with the negative control. We next examined whether let-7e regulates the formation of $\gamma \mathrm{H} 2 \mathrm{AX}$ foci after incubation with cisplatin, which is a surrogate marker of DSB [15]. Significantly increased cells with positive $\gamma \mathrm{H} 2 \mathrm{AX}$ foci were observed in the A2780 cells transfected with let-7e agomirs compared with control, while a remarkable decrease in $\gamma \mathrm{H} 2 \mathrm{AX}$ foci was shown in the $\mathrm{SKOV}_{3}$ cells transfected with let-7e inhibitors compared with control (Fig. 3b and Additional file 2: Figure S2).

Given that Rad51 and BRCA1 play a central role in HR-mediated DSB repair $[2,24,25]$ and govern the response of tumor cells to cisplatin [26, 27], we wondered whether let-7e regulates BRCA1 and Rad51 expression in EOC. Werstern blotting assays showed that the let-7e overexpression in A2780, OV2008 and C13K cells substantially decreased BRCA1 and Rad51 expression (Fig. 3c). Inversely, after transfection with let-7e inhibitors, BRCA1 and Rad51 protein levels were significantly increased compared with control (Fig. 3d). These findings suggest that let-7e inhibits the repair of cisplatininduced DSB might be partially achieved by downregulating BRCA1 and Rad51.

To further investigate the mechanisms of how let-7e impacts BRCA1 and Rad51 expression, we used miRWalk (http://zmf.umm.uni-heidelberg.de/apps/zmf/mirwalk2/) and microRNA.org (http://www.microrna.org/) to predict the target genes of let-7e. Among the search results, poly (ADP-ribose) polymerase 1 (PARP1) and insulin-like growth factor-1 (IGF-1) captured our attention because of their involvement in the regulation of BRCA1 and Rad51 expression and DSB repair [28, 29]. After treatment with let-7e agomir, the mRNA levels of PARP1 and IGF-1 were markedly decreased. Conversely, let-7e downregulation substantially increased the expression of PARP1 and IGF-1 (Fig. 3e and f).

\section{Expression and prognostic values of let-7e, BRCA1 and Rad51 in epithelia ovarian cancer}

Given the inhibitory regulation of BRCA1 and Rad51 by let-7e in vitro, a negative relationship of let-7e with 
Table 2 Associations of different parameters with PFS, OS and chemotherapy response of EOC patients

\begin{tabular}{|c|c|c|c|c|c|c|c|c|}
\hline \multirow[b]{2}{*}{ Variables } & \multirow[b]{2}{*}{ Case No. (\%) } & \multicolumn{2}{|l|}{$\mathrm{PFS}^{\mathrm{a}}$} & \multicolumn{2}{|l|}{$\operatorname{OS}^{a}$} & \multirow{2}{*}{$\begin{array}{l}\text { Case } \\
\text { No. (\%) }\end{array}$} & \multicolumn{2}{|c|}{ Chemotherapy response ${ }^{b}$} \\
\hline & & HR $(95 \% \mathrm{Cl})$ & $P$ Value & $\mathrm{HR}(95 \% \mathrm{Cl})$ & $P$ Value & & OR $(95 \% \mathrm{Cl})$ & $P$ Value \\
\hline \multicolumn{9}{|c|}{ Age at surgery, $y$} \\
\hline$<50$ & $25(40.3)$ & $0.921(0.439-1.932)$ & 0.828 & $0.763(0.329-1.771)$ & 0.529 & $23(40.3)$ & $1.094(0.346-3.461)$ & 0.879 \\
\hline$\geq 50$ & $37(59.4)$ & 1 & & 1 & & $35(59.4)$ & 1 & \\
\hline \multicolumn{9}{|c|}{ Histological subtypes } \\
\hline Serous & $50(80.6)$ & $1.493(0.567-3.93)$ & 0.417 & $1.153(0.390-3.412)$ & 0.796 & $46(80.6)$ & $2.419(0.47-12.454)$ & 0.291 \\
\hline Others & $12(19.4)$ & 1 & & 1 & & $12(19.4)$ & 1 & \\
\hline \multicolumn{9}{|c|}{ FIGO stage } \\
\hline$|-| \mid$ & $18(29.0)$ & $0.352(0.123-1.012)$ & 0.053 & $0.143(0.019-1.063)$ & 0.057 & $16(29.0)$ & $0.257(0.051-1.287)$ & 0.098 \\
\hline III-IV & $44(71.0)$ & 1 & & 1 & & $42(71.0)$ & 1 & \\
\hline \multicolumn{9}{|c|}{ Tumor categories } \\
\hline Type I & $15(24.2)$ & $0.647(0.263-1.587)$ & 0.341 & $0.762(0.281-2.071)$ & 0.595 & $15(24.2)$ & $0.518(0.126-2.136)$ & 0.363 \\
\hline Type II & $47(75.8)$ & 1 & & 1 & & $43(75.8)$ & 1 & \\
\hline \multicolumn{9}{|c|}{ Let-7e expression } \\
\hline Low & $23(37.1)$ & $3.204(1.541-6.661)$ & 0.002 & $4.368(1.804-10.575)$ & 0.001 & $21(37.1)$ & $22.667(5.114-100.457)$ & $<0.0001$ \\
\hline High & $39(62.9)$ & 1 & & 1 & & $37(62.9)$ & 1 & \\
\hline \multicolumn{9}{|c|}{ BRCA1 expression } \\
\hline Low & $25(40.3)$ & 1 & 0.078 & 1 & 0.350 & $23(40.3)$ & 1 & 0.011 \\
\hline High & $37(59.7)$ & $1.993(0.925-4.294)$ & & $1.510(0.636-3.585)$ & & $35(59.7)$ & 7.875 (1.594-38.906) & \\
\hline \multicolumn{9}{|c|}{ Rad51 expression } \\
\hline Low & $32(51.6)$ & 1 & 0.001 & 1 & 0.025 & $30(51.6)$ & 1 & 0.001 \\
\hline High & $30(48.4)$ & $3.584(1.668-7.701)$ & & $2.752(1.133-6.682)$ & & $28(48.4)$ & $16.154(3.212-81.252)$ & \\
\hline
\end{tabular}

EOC epithelial ovarian cancer, $H R$ hazards ratio, CI confidence interval, PFS progression-free survival, OS overall survival, OR odds ratio, FIGO International Federation of Gynecology and Obstetrics

${ }^{\mathrm{a}}$ Univariate Cox proportional hazards Regression analysis; ${ }^{\mathrm{b}}$ Univariate logistic regression analysis

BRCA1 and Rad51 in EOC is expected. Contrary to let7e expression, western blotting showed increased protein levels of BRCA1 and Rad51 in C13K cells compared with its paired sensitive line OV2008 (Fig. 4a). In line with the results in cells, IHC revealed significantly elevated expression of BRCA1 and Rad51 in the chemoresistant EOC tissues compared with the chemosensitive cases $\left(P_{B R C A 1}=0.0251, P_{R a d 51}=0.0001\right.$; Fig. $4 \mathrm{~b}$ c). In addition, both BRCA1 and Rad51 expression were negatively correlated with let-7e $\left(P_{B R C A 1}=0.0383, P_{\text {Rad51 }}\right.$ $=0.0016$; Fig. $4 \mathrm{~b}$ and d).

To investigate the possible prognostic values of let-7e, BRCA1 and Rad51 in ovarian cancer, we first analyzed their correlation with the clinicopathological characteristics of EOC patients. Low let-7e, high BRCA1 and high Rad51 were closely related with chemotherapy resistance $\left(P_{\text {let-7e }}<0.0001, P_{B R C A 1}=0.013, P_{\text {Rad } 51}<0.0001\right)$. Nevertheless, their expression was not significantly associated with age, FIGO stage, tumor categories or histological subtypes (Table 1). Next, univariate and multivariate Cox proportional hazards regression analyses were performed to assess the association between the expression of let-7e, BRCA1 and Rad51 and survival of patients. The univariate analyses indicated that advanced FIGO stage, low let-7e and high Rad51 were significantly associated with poor PFS and OS (Table 2). These results were confirmed by KaplanMeier analyses and log-rank tests $\left(P_{P F S / l e t-7 e}=0.0008, P_{O S /}\right.$ let-7e $=0.0003, P_{P F S / R a d 51}=0.0004, P_{\text {OS } / \text { Rad } 51}=0.0189, P_{P F S /}$ $B R C A 1=0.068$; Fig. $5 \mathrm{a}-\mathrm{e})$. The prognostic significance of BRCA1 and Rad51 was consistent with the observations in The Cancer Genome Atlas (TCGA) and Gene-Expression Omnibus database (Additional file 2: Figure S3). Multivariate analyses showed that low let-7e and high Rad51 were independent prognostic factors for OS (HR 3.235, 95\% CI 1.258-8.317) and PFS (HR 2.519, 95\% CI 1.098-5.779) in EOC, respectively (Table 3 ).

In order to evaluate the capacity of let-7e, BRCA1 and Rad51 expression to predict the sensitivity of EOC to platinum-taxane chemotherapy, ROC curves were established. The area under the curve (AUC) for let-7e, Rad51 and BRCA1 were 0.826 (sensitivity $82.4 \%$, specificity $82.9 \%$ ), 0.783 (sensitivity $88.2 \%$, specificity $68.3 \%$ ) and 0.697 (sensitivity $88.2 \%$, specificity $51.2 \%$ ) respectively (Fig. 5f). These results were further confirmed by univariate logistic regression analyses which showed that low let-7e, high Rad51 and high BRCA1 were all 
A
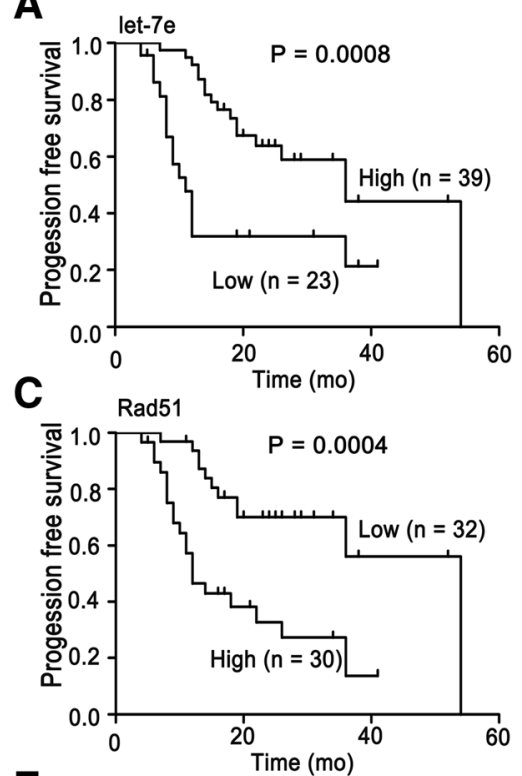

E

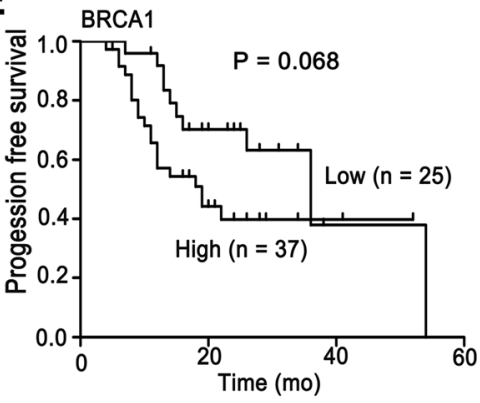

B
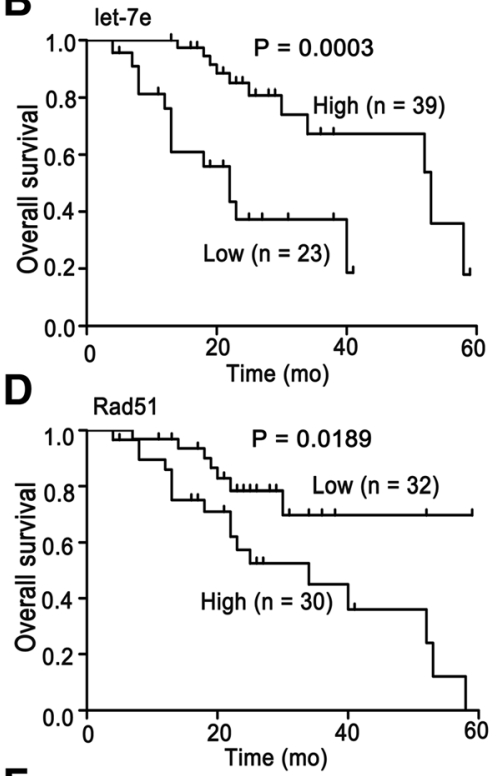

$\mathbf{F}$

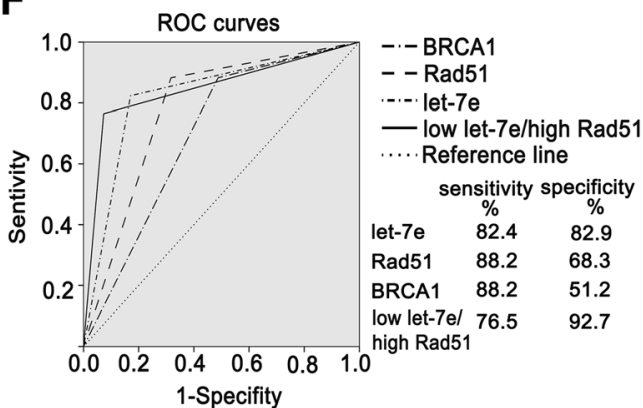

Fig. 5 Influence of let-7e, BRCA1 and Rad51 on predicting survival and sensitivity to chemotherapy in EOC. a-e Kaplan-Meier survival curves for EOC patients based on the expression of let-7e, Rad51 and BRCA1. a, PFS for let-7e; b, OS for let-7e; c, PFS for Rad51; d, OS for Rad51; e, PFS for BRCA1. Ovarian cancer patients were stratified into let-7e, Rad51 or BRCA1 low and high expression groups according to the mean scores of their expression. Log-rank test. $\mathbf{f}$ ROC curves of let-7e, Rad51, BRCA1 and the combination of low let-7e and high Rad51 ( $n=58)$. AUC let-7e $=0.826$, $P<0.0001 ; A U C_{\text {Rad51 }}=0.783, P=0.001 ; A U C_{B R C A 1}=0.697, P=0.019 ; A U C_{\text {low let-7e/high } \text { Rad51 }}=0.846, P<0.0001$

significantly correlated with chemotherapy resistance (Table 2). However, only let-7e was proved to be an independent factor to predict chemotherapy response indicated by multivariable logistic analysis $\left(P_{\text {let-7e }}=0.001\right.$; OR, 19.696; 95\% CI, 3.477-111.572; Table 3). In addition, the AUC of the ROC curve for the combination of low let-7e and high Rad51 achieved 0.846 with a specificity of $92.7 \%$ and a sensitivity of $76.5 \%$.

\section{Discussion}

Among the let-7 family members, let-7a and let-7b are proposed to be important regulators of chemo-response in tumor through regulating chemotherapeutic agentsinduced apoptosis $[10,30]$. Our previous study showed that let-7e was down-regulated in cisplatin-resistant EOC cell lines and re-expression of let-7e could sensitize cancer cells to cisplatin in vitro and in vivo. In the present study, we demonstrated that let-7e determines the fate of the EOC cells exposed to cisplatin through governing the repair of cisplatin-induced DSB and further verified the association between loss of let-7e and cisplatin-resistance in human EOC tissues. In addition, low let-7e was found to be an independent prediction factor for poor survival and resistance to platinum-based chemotherapy. These findings suggest that let-7e, similar to let-7a and let-7b, plays an essential role in cisplatinresistance and might be a promising predictor for chemotherapy response in EOC.

To survive and maintain genome integrity after receiving exogenous or endogenous stimuli, cells initiate their cellular DNA damage response system. DSB is the most deleterious form of DNA lesions, which leads to cell death when DNA repair was faulty or insufficient. BRCA1 and Rad51 are essential for HR-mediated DSB repair and are identified as targets of several miRNAs. MiR-9 inhibited cisplatin-induced BRCA1 and Rad51 
Table 3 Multivariate regression analysis of significant prediction factors on PFS,OS and chemotherapy response of EOC patients

\begin{tabular}{|c|c|c|c|c|c|c|c|c|}
\hline \multirow[b]{2}{*}{ Variables } & \multirow[b]{2}{*}{ Case No. (\%) } & \multicolumn{2}{|l|}{ PFS $^{a}$} & \multicolumn{2}{|l|}{$\mathrm{OS}^{\mathrm{a}}$} & \multirow[b]{2}{*}{ Case No. (\%) } & \multicolumn{2}{|c|}{ Chemotherapy response ${ }^{b}$} \\
\hline & & $\mathrm{HR}(95 \% \mathrm{Cl})$ & $P$ Value & $\mathrm{HR}(95 \% \mathrm{Cl})$ & $P$ Value & & OR $(95 \% \mathrm{Cl})$ & $P$ Value \\
\hline \multicolumn{9}{|c|}{ FIGO stage } \\
\hline$|-| \mid$ & $18(29.0)$ & $0.552(0.184-1.658)$ & 0.290 & $0.204(0.027-1.551)$ & 0.125 & $16(29.0)$ & - & - \\
\hline III-IV & $44(71.0)$ & 1 & & 1 & & $42(71.0)$ & & \\
\hline \multicolumn{9}{|c|}{ Let-7e expression } \\
\hline Low & $23(37.1)$ & $2.037(0.912-4.554)$ & 0.083 & $3.235(1.258-8.317)$ & 0.015 & $21(37.1)$ & 19.696 (3.477-111.572) & 0.001 \\
\hline High & $39(62.9)$ & 1 & & 1 & & $37(62.9)$ & 1 & \\
\hline \multicolumn{9}{|c|}{ BRCA1 expression } \\
\hline Low & $25(40.3)$ & - & - & - & - & $23(40.3)$ & 1 & 0.155 \\
\hline High & $37(59.7)$ & & & & & $35(59.7)$ & $5.042(0.541-47.011)$ & \\
\hline \multicolumn{9}{|c|}{ Rad51 expression } \\
\hline Low & $32(51.6)$ & 1 & 0.029 & 1 & 0.404 & $30(51.6)$ & 1 & 0.163 \\
\hline High & $30(48.4)$ & $2.519(1.098-5.779)$ & & $1.500(0.579-3.891)$ & & $28(48.4)$ & $4.290(0.553-33.26)$ & \\
\hline
\end{tabular}

EOC epithelial ovarian cancer, HR hazards ratio, $\mathrm{Cl}$ confidence interval, PFS progression-free survival, OS overall survival, OR odds ratio, FIGO International Federation of Gynecology and Obstetrics

${ }^{a}$ Multivariate Cox proportional hazards Regression analysis; ${ }^{b}$ Multivariate logistic regression analysis

foci formation by directly targeting BRCA1, leading to impaired DNA damage repair and restored sensitivity to cisplatin [31]. MiR-146a, miR-146b-5p and miR-182 are also reported to bind to the 3'-UTR of BRCA1, resulting in a reduction in BRCA1 and HR [32]. Over-expression of miR-506 and miR-103/107 decreased Rad51 expression and subsequently reduced HR-directed repair of DNA damage induced by cisplatin, leading to an augmented response to cisplatin [33, 34]. Here, we demonstrated that enhanced let-7e could reduce the repair of cisplatin-induced DSB and re-sensitize EOC cells to cisplatin through down-regulating BRCA1 and Rad51.

As we known, miRNA regulates gene expression through binding to the 3'-UTR of targeting mRNAs based on base paring. However, the 3'-UTRs of BRCA1 and Rad51 contain no putative let-7e binding site, suggesting that let-7e cannot directly target BRCA1 or Rad51 mRNA. Hegan DC et al. found that inhibition of PARP1 suppressed BRCA1 and Rad51 expression through stimulating repressive E2F4/p130 complexes to bind to the promoters of BRCA1 and Rad51 [28]. Jeon $\mathrm{JH}$ et al. reported that IGF- 1 attenuated the DNA repair of cisplatin-induced DSB, $\gamma$-H2AX foci formation and damage checkpoint pathway in non-small cell lung cancer [29]. Both PARP1 and IGF-1 are potential direct targets of let-7e according to miRWalk and microRNA.org, our study showed that let-7e negatively regulated the expression of PARP1 and IGF-1 in ovarian cancer cell lines, indicating that PARP1 and IGF-1 might link let-7e to Rad51 and BRCA1, although that remains to be verified in further studies.

The expression and function of let-7e are varied in different tumors. Let-7e was down-regulated in colorectal cancer, non-small-cell lung carcinoma, esophageal cancer, lymphoma and ovarian cancer and functioned as a tumor suppressor [35-39]. In contrast, an increased let-7e expression was observed in retinoblastoma and synovial sarcoma [40, 41]. These results suggest that the role of let-7e is tumor-specific. Although low let-7e was observed in ovarian cancer, its role in oncogenesis and progression of EOC remains unclear. In the present study, we found let-7e was decreased in chemo-resistant ovarian cancers compared with chemo-sensitive cases and was identified as an independent predictor for poor survival and chemo-resistance, suggesting a tumor-suppressive role of let-7e in EOC and highlighting the clinical value of let-7e for stratification of patients with risk to develop chemoresistance and to relapse. Moreover, let-7e emerged as a potential circulating biomarker for diseases. Serum let-7e level was significantly correlated with tumor size and metastasis status in papillary thyroid carcinoma [42]. Low serum let-7e was identified as a potential predictor for severe knee or hip osteoarthritis [43]. The plasma let-7e was found to be an early marker of metabolic syndrome in pediatric population [44]. Thus, future investigations should strive to incorporate let-7e detection, both in EOC tissue and in peripheral circulation, into clinical trials to evaluate whether let-7e can be used to guide decision making on usage of platinum-taxane chemotherapy and monitoring the response to chemotherapy during treatment in EOC.

Also, let-7e has been implicated in taxane resistance. The expression of almost all the let-7 family members 
(let-7a, let-7c, let-7d, let-7e, let-7f, let-7 g, let-7i and mir98) was reduced in a paclitaxel-resistant hepatocellular carcinoma cell line [45]. Ectopic let-7a, let-7b, let-7c and let-7 g expression rendered tumor cells more sensitive to taxol treatment in breast, pancreatic, colorectal, lung and ovarian cancer [46-49]. Although less frequent, upregulation of certain let-7 family members has also been observed in taxane resistant cancer cells. Tsang et al. demonstrated that enforced let-7a induced the resistance to apoptosis caused by paclitaxel in squamous carcinoma A431 cells and hepatocellular carcinoma HepG2 cells [50]. In ovarian cancer, let-7e was upregulated in paclitaxel resistant A2780 cells [51]. These conflicting data indicate that the function of let-7 family in taxane resistance may be tissue or cell type specific. Specially, contrast to the upregulation of let-7e in paclitaxel resistant EOC cell, let-7e was down-regulated in cisplatinresistant cell lines, suggesting that the role of let-7e in chemo-resistance may be drug-specific.

\section{Conclusions}

Our data demonstrate that low let-7e expression contributes to the development of chemo-resistance in EOC through impairing DNA DSB repair via regulating the expression of BRCA1 and Rad51 and is a potential predictor for poor survival and resistance to platinum-taxane chemotherapy in patients with EOC. However, the mechanism through which let-7e regulates BRCA1 and Rad51 remains unknown and the prognostic value of let-7e needs to be validated in prospective, large-scale studies.

\section{Additional files}

Additional file 1: Table S1. The sequences of PCR primers used in this study. (DOCX $13 \mathrm{~kb}$ )

Additional file 2: Figure S1. Influence of let-7e inhibitor on the mRNA levels of RFX6, CASP3, MMP9 and EZH2. Student's $t$-test, ${ }^{*} P<0.05,{ }^{*} P<$ $0.01,{ }^{* *} P<0.001$. Figure S2. qRT-PCR analysis of let-7e expression in $\mathrm{SKOV}_{3}$ cells after transfection with let-7e inhibitor. Student's t-test, ${ }^{* *} p<0.001$. Figure S3. Associations of Rad51 and BRCA1 expression with prognosis of ovarian cancer patients in publically available datasets. (DOCX 202 kb)

\section{Abbreviations}

AP: Alkaline phosphatase; ATM: Ataxia telangiectasia mutated; ATR: Ataxia Rad3-related; AUC: Area under the curve; BSA: Bovine serum albumin; CASP: Comet Assay Software Project; CASP3: Caspase 3; CCTCC: China Center for Type Culture Collection; Cl: Confidence interval; DMEM: Dulbecco's Modified Eagle Medium; DSB: Double strand break; EOC: Epithelial ovarian cancer; EZH2: Enhancer of zeste 2; FFPE: Formalin-fixed and paraffin embedded; FIGO: International Federation of Gynecology and Obstetrics; HR: Hazards ratio; HR: Homologous recombination; IGF-1: insulin-like growth factor-1; IHC: Immunohistochemistry; IR: Ionizing radiation; ISH: In situ hybridization; LMP: Low melting point; LNA: Locked Nucleic Acids; MMP9: Matrix metalloproteinase-9; NHEJ: Non-homologous end-joining; OS: Overall survival; PARP1: Poly(ADP-ribose) polymerase 1; PBST: PBS containing 0.1\% Tween-20; PFS: Profession-free survival; RFX6: Regulatory factor X 6; ROC: Receiver operating characteristic; SSC: Standard saline citrate; TM: Tail moment; UTR: Untranslated region

\section{Acknowledgements}

We would like to thank the support of the National Natural Science Foundation of China.

\section{Funding}

This work was supported by grants from the National Natural Science Foundation of China (No. 81101961, 81572572, 81502248, 81302265 and 81272860).

\section{Authors' contributions}

JC and ZW conceived and designed the research. MX, LC and JJ performed the experiments and analyzed the data. $L X, Y Z, B H$ and DJ provided administrative and technical support. MX and JC wrote the manuscript. All authors read and approved the final manuscript.

\section{Availability of data and materials}

The datasets generated during and/or analysed during the current study can be available from the corresponding author on reasonable request.

Competing interests

The authors declare that they have no competing interests.

Consent for publication

Not applicable.

Ethics approval and consent to participate

The use of specimens and archiving of patient data were approved by the ethical committee of Union Hospital.

\section{Publisher's Note}

Springer Nature remains neutral with regard to jurisdictional claims in published maps and institutional affiliations.

\section{Author details}

${ }^{1}$ Department of Obstetrics and Gynecology, Union Hospital, Tongji Medical College, Huazhong University of Science and Technology, No. 1277 Jiefang Avenue, Wuhan 430022, China. ${ }^{2}$ Department of Obstetrics and Gynecology, Air Force General Hospital, PLA, Beijing 100142, China. ${ }^{3}$ Department of Pathology, Union Hospital, Tongji Medical College, Huazhong University of Science and Technology, No. 1277 Jiefang Avenue, Wuhan 430022, China.

Received: 23 August 2016 Accepted: 28 March 2017

Published online: 04 April 2017

\section{References}

1. Chen W, Zheng R, Baade PD, Zhang S, Zeng H, Bray F, et al. Cancer statistics in China, 2015. CA Cancer J Clin. 2016;66(2):115-32.

2. Moynahan ME, Chiu JW, Koller BH, Jasin M. Brca1 controls homologydirected DNA repair. Mol Cell. 1999:4(4):511-8.

3. Choi YE, Meghani K, Brault ME, Leclerc L, He YJ, Day TA, et al. Platinum and PARP inhibitor resistance Due to overexpression of MicroRNA-622 in BRCA1mutant ovarian cancer. Cell Rep. 2016;14(3):429-39.

4. Sakogawa K, Aoki Y, Misumi K, Hamai Y, Emi M, Hihara J, et al. Involvement of homologous recombination in the synergism between cisplatin and poly (ADP-ribose) polymerase inhibition. Cancer Sci. 2013; 104(12):1593-9.

5. Cavallo F, Graziani G, Antinozzi C, Feldman DR, Houldsworth J, Bosl GJ, et al. Reduced proficiency in homologous recombination underlies the high sensitivity of embryonal carcinoma testicular germ cell tumors to Cisplatin and poly (adp-ribose) polymerase inhibition. PLoS One. 2012;7(12):e51563.

6. Wang QE, Milum K, Han C, Huang YW, Wani G, Thomale J, et al. Differential contributory roles of nucleotide excision and homologous recombination repair for enhancing cisplatin sensitivity in human ovarian cancer cells. Mol Cancer. 2011;10:24.

7. Bagga S, Bracht J, Hunter S, Massirer K, Holtz J, Eachus R, et al. Regulation by let-7 and lin-4 miRNAs results in target mRNA degradation. Cell. 2005; 122(4):553-63.

8. Sun KX, Jiao JW, Chen S, Liu BL, Zhao Y. MicroRNA-186 induces sensitivity of ovarian cancer cells to paclitaxel and cisplatin by targeting ABCB1. J Ovarian Res. 2015;8:80. 
9. Drayton RM. The role of microRNA in the response to cisplatin treatment. Biochem Soc Trans. 2012;40(4):821-5.

10. Boyerinas B, Park SM, Hau A, Murmann AE, Peter ME. The role of let-7 in cell differentiation and cancer. Endocr Relat Cancer. 2010;17(1):F19-36.

11. Cai J, Yang C, Yang Q, Ding H, Jia J, Guo J, et al. Deregulation of let-7e in epithelial ovarian cancer promotes the development of resistance to cisplatin. Oncogenesis. 2013;2:e75.

12. Chaudhry MA. Real-time PCR, analysis of micro-RNA expression in ionizing radiation-treated cells. Cancer Biother Radiopharm. 2009;24(1):49-56.

13. Nikiforova MN, Gandhi M, Kelly L, Nikiforov YE. MicroRNA dysregulation in human thyroid cells following exposure to ionizing radiation. Thyroid. 2011;21(3):261-6.

14. Wang Y, Huang JW, Li M, Cavenee WK, Mitchell PS, Zhou X, et al. MicroRNA138 modulates DNA damage response by repressing histone $\mathrm{H} 2 \mathrm{AX}$ expression. Mol Cancer Res. 2011;9(8):1100-11.

15. Redon C, Pilch D, Rogakou E, Sedelnikova O, Newrock K, Bonner W. Histone H2A variants H2AX and H2AZ. Curr Opin Genet Dev. 2002;12(2):162-9.

16. Davis A, Tinker AV, Friedlander M. "Platinum resistant" ovarian cancer: what is it, who to treat and how to measure benefit? Gynecol Oncol. 2014;133(3):624-31.

17. Jorgensen S, Baker A, Moller S, Nielsen BS. Robust one-day in situ hybridization protocol for detection of microRNAs in paraffin samples using LNA probes. Methods. 2010;52(4):375-81.

18. Wojewodzka M, Buraczewska I, Kruszewski M. A modified neutral comet assay: elimination of lysis at high temperature and validation of the assay with anti-single-stranded DNA antibody. Mutat Res. 2002;518(1):9-20.

19. Olive PL, Wlodek D, Durand RE, Banath JP. Factors influencing DNA migration from individual cells subjected to gel electrophoresis. Exp Cell Res. 1992;198(2):259-67.

20. Liao X, Xue H, Wang YC, Nazor KL, Guo S, Trivedi N, et al. Matched miRNA and mRNA signatures from an hESC-based in vitro model of pancreatic differentiation reveal novel regulatory interactions. J Cell Sci. 2013;126(Pt 17):3848-61.

21. Sharbati J, Lewin A, Kutz-Lohroff B, Kamal E, Einspanier R, Sharbati S. Integrated microRNA-mRNA-analysis of human monocyte derived macrophages upon Mycobacterium avium subsp. hominissuis infection. PLoS One. 2011;6(5):e20258.

22. Ventayol M, Vinas JL, Sola A, Jung M, Brune B, Pi F, et al. miRNA let-7e targeting MMP9 is involved in adiposederived stem cell differentiation toward epithelia. Cell Death Dis. 2014;5:e1048.

23. Vishnubalaji R, Hamam R, Abdulla MH, Mohammed MA, Kassem M, Al-Obeed $\mathrm{O}$, et al. Genome-wide mRNA and miRNA expression profiling reveal multiple regulatory networks in colorectal cancer. Cell Death Dis. 2015;6:e1614.

24. Baumann P, Benson FE, West SC. Human Rad51 protein promotes ATPdependent homologous pairing and strand transfer reactions in vitro. Cell. 1996:87(4):757-66.

25. Ledermann JA, Drew Y, Kristeleit RS. Homologous recombination deficiency and ovarian cancer. Eur J Cancer. 2016;60:49-58.

26. Takenaka T, Yoshino I, Kouso H, Ohba T, Yohena T, Osoegawa A, et al. Combined evaluation of Rad51 and ERCC1 expressions for sensitivity to platinum agents in non-small cell lung cancer. Int J Cancer. 2007;121(4):895-900.

27. Boyd J, Sonoda Y, Federici MG, Bogomolniy F, Rhei E, Maresco DL, et al. Clinicopathologic features of BRCA-linked and sporadic ovarian cancer. JAMA. 2000;283(17):2260-5

28. Hegan DC, Lu Y, Stachelek GC, Crosby ME, Bindra RS, Glazer PM. Inhibition of poly (ADP-ribose) polymerase down-regulates BRCA1 and RAD51 in a pathway mediated by E2F4 and p130. Proc Natl Acad Sci U S A. 2010;107(5):2201-6.

29. Jeon JH, Kim SK, Kim HJ, Chang J, Ahn CM, Chang YS. Insulin-like growth factor-1 attenuates cisplatin-induced gammaH2AX formation and DNA double-strand breaks repair pathway in non-small cell lung cancer. Cancer Lett. 2008;272(2):232-41.

30. Guo Y, Yan K, Fang J, Qu Q, Zhou M, Chen F. Let-7b expression determines response to chemotherapy through the regulation of cyclin D1 in glioblastoma. J Exp Clin Cancer Res. 2013;32:41.

31. Sun C, Li N, Yang Z, Zhou B, He Y, Weng D, et al. miR-9 regulation of BRCA1 and ovarian cancer sensitivity to cisplatin and PARP inhibition. J Natl Cancer Inst. 2013;105(22):1750-8.

32. Chang S, Sharan SK. BRCA1 and microRNAs: emerging networks and potential therapeutic targets. Mol Cells. 2012;34(5):425-32.

33. Liu G, Yang D, Rupaimoole R, Pecot CV, Sun Y, Mangala LS, et al. Augmentation of response to chemotherapy by microRNA-506 through regulation of RAD51 in serous ovarian cancers. J Natl Cancer Inst. 2015; 107(7):djv108.
34. Huang JW, Wang Y, Dhillon KK, Calses P, Villegas E, Mitchell PS, et al. Systematic screen identifies miRNAs that target RAD51 and RAD51D to enhance chemosensitivity. Mol Cancer Res. 2013;11(12):1564-73.

35. Kanaan Z, Rai SN, Eichenberger MR, Barnes C, Dworkin AM, Weller C, et al. Differential microRNA expression tracks neoplastic progression in inflammatory bowel disease-associated colorectal cancer. Hum Mutat. 2012 33(3):551-60.

36. Zhang YK, Zhu WY, He JY, Chen DD, Huang YY, Le HB, et al. miRNAs expression profiling to distinguish lung squamous-cell carcinoma from adenocarcinoma subtypes. J Cancer Res Clin Oncol. 2012;138(10):1641-50.

37. Zhao BS, Liu SG, Wang TY, Ji YH, Qi B, Tao YP, et al. Screening of microRNA in patients with esophageal cancer at same tumor node metastasis stage with different prognoses. Asian Pac J Cancer Prev. 2013;14(1):139-43.

38. de Oliveira JC, Scrideli CA, Brassesco MS, Morales AG, Pezuk JA, Queiroz Rde $P$, et al. Differential miRNA expression in childhood acute lymphoblastic leukemia and association with clinical and biological features. Leuk Res. 2012:36(3):293-8.

39. Dahiya N, Sherman-Baust CA, Wang TL, Davidson B, Shih le M, Zhang Y, et al. MicroRNA expression and identification of putative miRNA targets in ovarian cancer. PLoS One. 2008;3(6):e2436.

40. Zhao JJ, Yang J, Lin J, Yao N, Zhu Y, Zheng J, et al. Identification of miRNAs associated with tumorigenesis of retinoblastoma by miRNA microarray analysis. Childs Nerv Syst. 2009;25(1):13-20.

41. Hisaoka M, Matsuyama A, Nagao Y, Luan L, Kuroda T, Akiyama H, et al. Identification of altered MicroRNA expression patterns in synovial sarcoma. Genes Chromosomes Cancer. 2011;50(3):137-45.

42. Yu S, Liu Y, Wang J, Guo Z, Zhang Q, Yu F, et al. Circulating microRNA profiles as potential biomarkers for diagnosis of papillary thyroid carcinoma. J Clin Endocrinol Metab. 2012;97(6):2084-92

43. Beyer C, Zampetaki A, Lin NY, Kleyer A, Perricone C, lagnocco A, et al. Signature of circulating microRNAs in osteoarthritis. Ann Rheum Dis. 2015;74(3):e18.

44. Krause BJ, Carrasco-Wong I, Dominguez A, Arnaiz P, Farias M, Barja S, et al. Micro-RNAs Let7e and 126 in plasma as markers of metabolic dysfunction in 10 to 12 years Old children. PLoS One. 2015;10(6):e0128140.

45. Tian N, Han Z, Li Z, Zhou M, Fan C. Lin28/let-7/BCl-xL pathway: the underlying mechanism of drug resistance in Hep3B cells. Oncol Rep. 2014;32(3):1050-6.

46. Lv K, Liu L, Wang L, Yu J, Liu X, Cheng Y, et al. Lin28 mediates paclitaxel resistance by modulating p21, Rb and Let-7a miRNA in breast cancer cells. PLoS One. 2012;7(7):e40008.

47. Dai $X$, Jiang $Y$, Tan C. Let-7 sensitizes KRAS mutant tumor cells to chemotherapy. PLoS One. 2015;10(5):e0126653.

48. Cui SY, Huang JY, Chen YT, Song HZ, Feng B, Huang GC, et al. Let-7C governs the acquisition of chemo- or radioresistance and epithelial-tomesenchymal transition phenotypes in docetaxel-resistant lung adenocarcinoma. Mol Cancer Res. 2013;11(7):699-713.

49. Boyerinas B, Park SM, Murmann AE, Gwin K, Montag AG, Zillhardt M, et al. Let-7 modulates acquired resistance of ovarian cancer to Taxanes via IMP-1-mediated stabilization of multidrug resistance 1. Int J Cancer. 2012:130(8):1787-97.

50. Tsang WP, Kwok TT. Let-7a microRNA suppresses therapeutics-induced cancer cell death by targeting caspase-3. Apoptosis. 2008;13(10):1215-22.

51. Sorrentino A, Liu CG, Addario A, Peschle C, Scambia G, Ferlini C. Role of microRNAs in drug-resistant ovarian cancer cells. Gynecol Oncol. 2008; 111(3):478-86.

\section{Submit your next manuscript to BioMed Central and we will help you at every step:}

- We accept pre-submission inquiries

- Our selector tool helps you to find the most relevant journal

- We provide round the clock customer support

- Convenient online submission

- Thorough peer review

- Inclusion in PubMed and all major indexing services

- Maximum visibility for your research

Submit your manuscript at www.biomedcentral.com/submit 